Technical Note

\title{
A Physical Pre-Treatment Method (Vertical Weir Curtain) for Mitigating Cyanobacteria and Some of Their Metabolites in a Drinking Water Reservoir
}

\author{
Chae-Hong Park ${ }^{1}$, Myung-Hwan Park ${ }^{1, *}$ (1), Keun-Hee Kim ${ }^{1}$, Nan-Young Kim ${ }^{1}$, \\ Young-Hyo Kim ${ }^{2}$, Eun-Mi Gwon ${ }^{3}$, Baik-Ho Kim ${ }^{4}{ }^{\mathbb{D}}$, Byung-Jin Lim ${ }^{5}$ \\ and Soon-Jin Hwang ${ }^{1, *}$ \\ 1 Department of Environmental Health Science, Konkuk University, 120, Neungdong-ro, Gwangjin-gu, \\ Seoul 05029, Korea; qkrcoghd2@gmail.com (C.-H.P.); passbosko@gmail.com (K.-H.K.); \\ celeste0@naver.com (N.-Y.K.) \\ 2 Department of Environmental Science, Hanyang University, Seoul 04763, Korea; sonofthewind@hanmail.net \\ 3 ECOSTAR Ltd., 265 Jungdae-ro, Songpa-gu, Seoul 05660, Korea; emgwon@hanmail.net \\ 4 Department of Life Science, Hanyang University, 222, Wangsimni-ro, Seongdong-gu, Seoul 04763, Korea; \\ tigerk@hanyang.ac.kr \\ 5 National Institute of Environmental Research, 42, Hwangyong-ro, Seo-gu, Incheon 22689, Korea; \\ limnolim@korea.kr \\ * Correspondence: parkmh96@konkuk.ac.kr (M.-H.P.); sjhwang@konkuk.ac.kr (S.-J.H.)
}

Received: 27 August 2017; Accepted: 3 October 2017; Published: 11 October 2017

\begin{abstract}
Harmful cyanobacteria and their metabolites often contaminate drinking water resources, and effective control remains challenging. Here, we developed a physical algal pre-treatment method, the vertical weir curtain (VWC), to mitigate cyanobacteria and some of their metabolites (geosmin, 2-methylisoborneol (2-MIB), and microcystins) in situ and evaluated its performance in a raw water reservoir used for drinking water supply. The VWC was manufactured with two fibrous polypropylene mats ( $0 \%$ and $92 \%$ porosity) which were mounted to maintain a constant underwater depth. We installed the VWC to cover the entire epilimnion of the drinking water intake zone and monitored its efficiency during an algal bloom period (July-October 2015). Reduction rates were $40-59 \%$ for total algae, $60-75 \%$ for cyanobacteria, $23-55 \%$ for geosmin, $30-51 \%$ for $2-\mathrm{MIB}$, and $47-89 \%$ for microcystin-LR during the study period. Significant reductions were observed in the shallow layer of the water column (1-3 m water depth), particularly during August, when cyanobacterial density was the highest. The results indicate that the VWC can effectively mitigate harmful cyanobacteria and their metabolites when suitably applied, serving as a valuable reference for the algal reduction in raw drinking water resources.
\end{abstract}

Keywords: cyanobacteria; drinking water; microcystins; odor compounds; pre-treatment; vertical weir curtain

\section{Introduction}

Harmful cyanobacteria and their metabolites, such as off-flavors (e.g., geosmin and 2-methylisoborneol (2-MIB)) and toxins, are nuisances for water resource management [1], particularly in drinking water reservoirs. Off-flavor compounds cause an unpleasant odor and earthy and musty taste that can be perceived by humans even at very low concentrations (ca. 10-20 ng/L) [2]. Moreover, various toxins of cyanobacterial origin are associated with adverse effects on both ambient organisms and human health [3].

Thus far, the management of off-flavors and cyanotoxins has focused primarily on treatment methods in water purification facilities rather than the control of the cyanobacteria concerned and 
the ultimate factors responsible for their production in nature. Existing methods for the removal of off-flavors and toxins in drinking water include various materials (e.g., treatments using potassium permanganate, chlorine, ozone, and activated carbon) [4,5]. However, some of these methods have been known to produce harmful by-products during the treatment process and are less effective with higher concentrations of organic matter in the source water [6,7]. Moreover, they can cause water utilities to incur considerable expenses. Therefore, it would be highly beneficial to reduce the massive blooms of cyanobacteria and their metabolites in raw water before intake into the treatment plant for the effective operation of treatment facilities, thereby lowering treatment costs.

Various techniques for the pre-treatment and control of cyanobacteria using physical methods have been studied in the field of drinking water supply [8-10], as odorants and cyanotoxins have long been considered in drinking water quality and safety [3,11]. Many traditional preventive measures developed for water treatment systems may not have sufficient merit in practice because of high operating costs to remove cyanobacteria and their secondary metabolites (geosmin, 2-MIB, and cyanotoxins). In situ physical pre-treatment aims to decrease cyanobacterial densities in raw water before entering the water treatment plant $[8,10]$. So-called algal fences and their derivatives have been frequently applied in various water intake systems to inhibit algae from spreading over the area of water intake and to prevent the inflow of algal cells to the intake facility $[8,9,12,13]$. However, these showed low efficacy in removing cyanobacteria due to structural problems attributed to rolling-up of the fence, porosity, and durability. Recently, we developed a physical device, the vertical weir curtain (VWC), to mitigate contamination by cyanobacteria and their metabolites. The VWC represents a modification and improvement of the traditional algal fence to achieve high efficiency and applicability.

The objective of this study is to assess the performance of the VWC in reducing cyanobacteria and their harmful metabolites near a water intake facility in a drinking water reservoir during the summer and autumn. We report the effective reduction of nuisance cyanobacteria as well as their harmful metabolites, including odorous compounds and microcystins, in raw water by the VWC.

\section{Materials and Methods}

\subsection{Study Site}

The Paldang Reservoir is the largest drinking water resource in South Korea, serving 25 million people residing in the Seoul metropolitan area and its satellite cities. Its storage capacity and maximum depth are $2.44 \times 10^{8} \mathrm{~m}^{3}$ and $24.3 \mathrm{~m}$, respectively. A drinking water treatment plant is located near the dam, with a water intake capacity of $7.81 \times 10^{6} \mathrm{~m}^{3} /$ day. In the water intake facility with the VWC, water intake capacity was $1.50 \times 10^{6} \mathrm{~m}^{3} /$ day. The Paldang Reservoir is eutrophic and experiences massive cyanobacterial blooms every summer $[14,15]$. Cyanobacteria, particularly Dolichospermum circinale (formerly Anabaena circinalis) are a major source of off-flavors in this system [16,17]. Particularly, severe D. circinale bloom occurred in the downstream area of the reservoir during late fall of 2011 in which cell density and geosmin concentration in the raw water soared to their maximum record: 11,325 cells $/ \mathrm{mL}$ and $1640 \mathrm{ng} / \mathrm{L}$, respectively [16]. This episodic event caused complaints about even treated drinking water by the users. In addition, $D$. circinale and Microcystis spp. have also been reported to produce geosmin and cyanotoxins, respectively, in the Paldang Reservoir [18].

\subsection{Design and Installation of the VWC}

A schematic diagram of the VWC is shown in Figure 1, and its specifications are summarized in Table 1. The curtain was constructed of fibrous polypropylene in two layers. The upper layer was designed as a waterproofing mat, and the lower layer as a particle blocking mat; the two were connected into a single piece, with vertical lengths of $2 \mathrm{~m}$ and $3 \mathrm{~m}$, respectively, and a thickness of $20 \mathrm{~mm}$ each. The completed VWC was $5 \mathrm{~m}$ long to cover the entire epilimnion layer $(<5 \mathrm{~m})$ of the 
application site of the study reservoir when installed. The horizontal length of the VWC was $100 \mathrm{~m}$. The maximum depth of the study site was $8 \mathrm{~m}$. The total water depth under VWC was $3 \mathrm{~m}$ and it was stable all along the monitoring period.
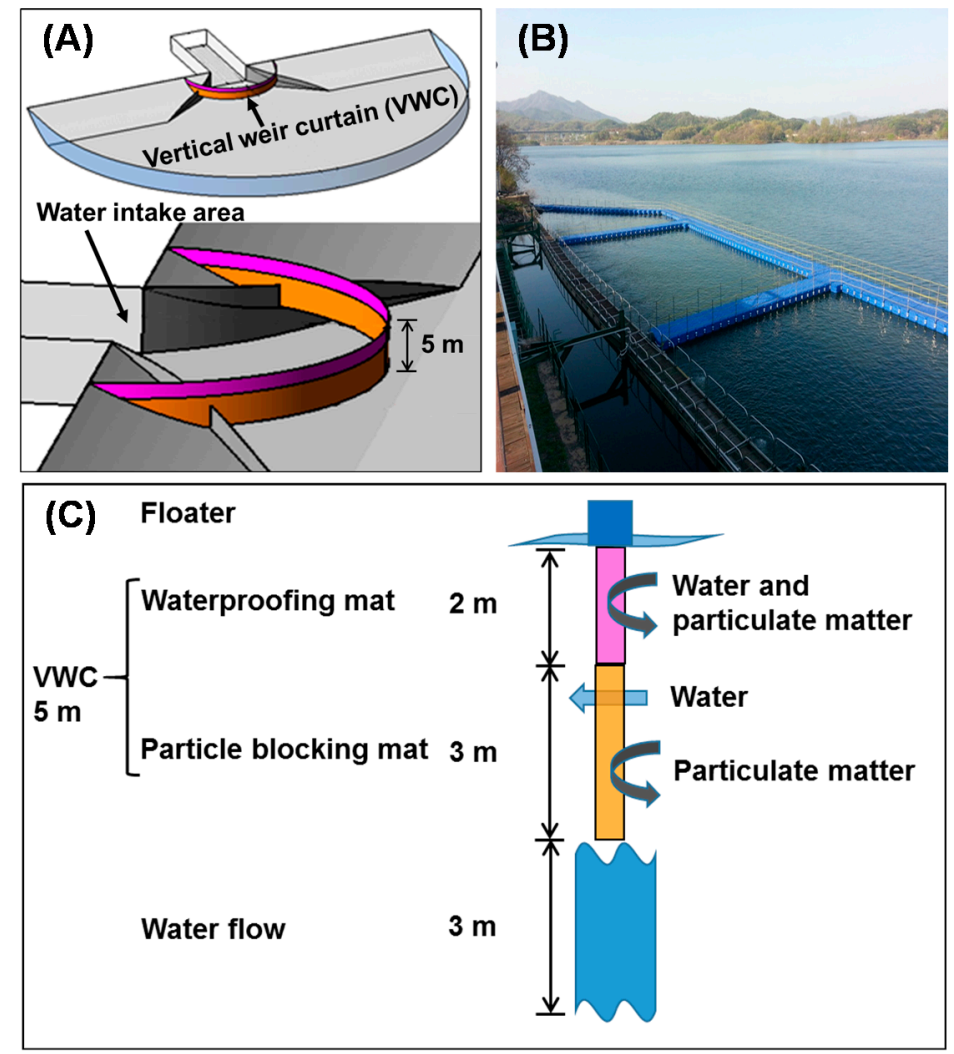

Figure 1. Schematic diagrams of the VWC structure and installation. (A) Diagram of the VWC installation around the intake area of the drinking water treatment facility; (B) photo of the floaters of the VWC; and (C) a vertical diagram of the VWC consisting of two mats, showing the position and the role of each mat in the underwater environment.

Table 1. Specifications of the vertical weir curtain (VWC), designed with an upper waterproofing mat and lower particle blocking mat.

\begin{tabular}{ccc}
\hline Specifications & Waterproofing Mat & Particle Blocking Mat \\
\hline Material & Polypropylene & Polypropylene (fibrous) \\
Thickness & $20 \mathrm{~mm}$ & $20 \mathrm{~mm}$ \\
Horizontal length & $100 \mathrm{~m}$ & $100 \mathrm{~m}$ \\
Vertical length & $2 \mathrm{~m}$ & $3 \mathrm{~m}$ \\
Pore size & $0 \mu \mathrm{m}$ & $100 \mu \mathrm{m}$ \\
Porosity & $0 \%$ & $92 \%$ \\
Flow velocity & $0 \mathrm{~m} / \mathrm{s}$ & $0.02-0.03 \mathrm{~m} / \mathrm{s}$ \\
Filtration resistance & Water, Particle & Particle \\
\hline
\end{tabular}

In order to determine the pore size of the particle blocking mat, we pre-screened the efficiencies of different pore sizes $(50,100$, and $200 \mu \mathrm{m})$ of the mat, in the consideration of both filtering capacity and pore occlusion. We prepared three cylindrical pilot mats (each with $1 \mathrm{~m}$ diameter $\times 3 \mathrm{~m}$ length) with three different pore sizes, applied to the same water body for our work during a cyanobacterial (Microcystis aeruginosa) bloom period ( $>10,000$ cells $/ \mathrm{mL}$ ) for $24 \mathrm{~h}$, and measured their efficiencies by comparing cell densities and Chl- $a$ concentrations inside and outside the cylindrical mats. The highest combined efficiency (i.e., high filtering and less occlusion) was observed with the pore size of 
$100 \mu \mathrm{m}$ (data not shown). Thus, the particle blocking mat provided the function of a filter screen consisting of a mesh filter with a pore size of $100 \mu \mathrm{m}$ and porosity of $92 \%$. The particle blocking mat had little filtration resistance to water due to its high porosity. The waterproofing mat was impermeable to both particles and water, and it was positioned on the upper part of the VWC (Figure 1), as massive cyanobacterial blooms usually occur in the upper layer of the water column in the study reservoir [14,17].

The VWC was installed surrounding the water intake area in order to reduce the entrance of biosestons into the water intake facility (Figure 1). The VWC was mounted on a floater to maintain a constant depth of $5 \mathrm{~m}$ below the water surface.

\subsection{Field Monitoring and Analysis}

We conducted field monitoring after the installation of the VWC around the water intake facility $\left(37^{\circ} 52^{\prime} \mathrm{N}, 127^{\circ} 28^{\prime} \mathrm{E}\right)$ in the Paldang Reservoir. Monitoring and analysis of total algae and cyanobacteria were conducted biweekly from July to October 2015. At sampling sites on both the inside and outside of the VWC, environmental factors, including water temperature, dissolved oxygen (DO), and $\mathrm{pH}$, were measured in situ using a portable water quality meter (YSI-6600-V2; YSI Inc., Yellow Springs, $\mathrm{OH}, \mathrm{USA})$.

Water samples were taken at the same depths $(1,3,5$, and $7 \mathrm{~m})$ both inside and outside of the VWC using a 5-L Van Dorn sampler (Go-Flo; General Oceanics, Inc., Miami, FL, USA); these were transferred to the laboratory within $6 \mathrm{~h}$ and analyzed within $24 \mathrm{~h}$. Odor compounds were determined for geosmin and 2-MIB, and toxins were analyzed for microcystins, including microcystin-LA (MC-LA), microcystin-LR (MC-LR), microcystin-RR (MC-RR), and microcystin-YR (MC-YR). Odor compounds were monitored at depths of 1,3,5, and $7 \mathrm{~m}$ on 18 August and 8 September, and microcystins were monitored at depths of 1,3 , and $7 \mathrm{~m}$ on 7 July and 18 August.

Algal enumeration was performed in triplicate according to the Sedgwick-Rafter Counting Chamber method [19] under a light microscope (CK X41; Olympus, Tokyo, Japan) after preservation with $2 \%(v / v)$ Lugol's solution, as described by Akiyama et al. [20]. The presence of geosmin and 2-MIB in raw water was determined using the method of headspace solid-phase micro-extraction (HS-SPME) coupled with gas chromatography-mass spectrometry (GC-MS) [21,22]. The conditions of HS-SPME, such as salt amount, extraction time, and extraction temperature, were optimized based on orthogonal analysis [21]. Microcystin derivatives (MC-LA, MC-LR, MC-RR, and MC-YR) in raw water were analyzed using liquid chromatography-mass spectrometry (LC-MS) [23,24]. Microcystin concentrations were determined by comparing peak areas with that of the standard (Sigma-Aldrich, Saint Louis, MS, USA). Concentrations were calculated as the sum of the cellular microcystin and dissolved microcystin values.

Rates of reduction (\%) in algae, odorous compounds, and microcystins as a result of the VWC were calculated for each parameter by the following equation: Reduction efficiency $(\%)=$ $(1-$ (inside VWC/outside VWC) $) \times 100$. Statistical differences in the concentrations of cyanobacteria, odorous compounds, and microcystins between the inside (treatment) and outside (control) of the VWC were evaluated by ANOVA using STAT (ver. 18.0. SPSS INC., Chicago, IL, USA). Significance was determined at $p<0.05$.

\section{Results and Discussion}

\subsection{Effects on Basic Water Quality Variables}

The water temperature (WT) of the surface layer ( $1 \mathrm{~m}$ depth) varied between 18.7 and $28.2{ }^{\circ} \mathrm{C}$, with only minimal differences between the two sides of the VWC during the study period (Figure 2A). The DO ranged from 6.83 to $9.25 \mathrm{mg} / \mathrm{L}$ (Figure 2B), and the $\mathrm{pH}$ varied between 7.51 and 8.71 (Figure 2C). All water temperature, $\mathrm{DO}$, and $\mathrm{pH}$ values were higher on the outside than on the inside of the VWC, and the difference was noticeable in August, especially for DO and $\mathrm{pH}$. Water temperature in the 
internal area of the VWC was $0.1-0.6^{\circ} \mathrm{C}$ lower than that on the outside of the VWC due to the shadow effect. However, this difference was not significant $(p>0.05)$. In the internal area of the VWC, the DO was reduced by $0.04-1.53 \mathrm{mg} / \mathrm{L}$, and the $\mathrm{pH}$ also decreased by $0.02-0.55$ compared with that on the outside of the VWC, with the exception of measurements from 23 September and 6 October. The difference in temperature between the two sides was slightly higher in July and August than in September and October. In particular, differences in all variables were highest in August due to low values inside the VWC, which presumably resulted from the treatment effect, with differences of $0.6^{\circ} \mathrm{C}$ in WT, $1.53 \mathrm{mg} / \mathrm{L}$ in $\mathrm{DO}$, and 0.55 in $\mathrm{pH}$.
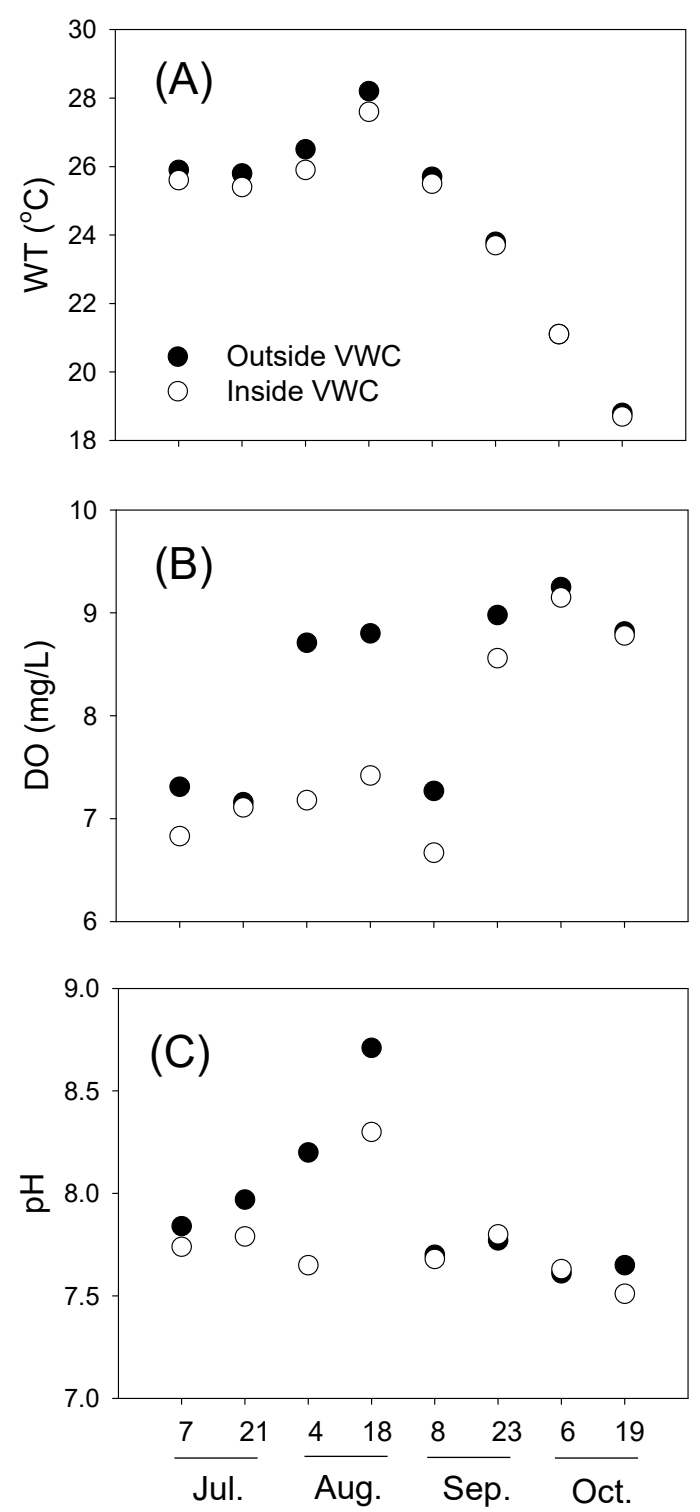

Figure 2. Variation in basic water quality variables in the surface water (1 $\mathrm{m}$ depth), both on the inside and the outside of the VWC during the study period. (A) Water temperature (WT); (B) dissolved oxygen (DO); and (C) pH.

In addition to algal reduction directly caused by the VWC, the shading effect, resulting in a temperature decrease, might hinder algal photosynthesis and thereby cause a decline in both DO and $\mathrm{pH}$ within the VWC [25]. A prior study validated the applicability of algae control by partial light-shading [10]. Such changes in physical conditions are typical effects of the vertical curtain and light-shading that may induce algal reduction $[8,10]$. Bowmer et al. [26] showed that for D. circinale, 
the most dominant species in our study area, the ratio of geosmin concentration to algal biomass was correlated with light intensity.

\subsection{Effects on Total Algae and Cyanobacteria}

Figure 3 demonstrates vertical changes in algal and cyanobacterial densities both inside and outside the VWC. During the study period between July and October, the total algal density ranged from 168 to 16,584 cells $/ \mathrm{mL}$, and the cyanobacterial density varied between 0 and 13,104 cells $/ \mathrm{mL}$. The overall vertical profile of the cyanobacterial density was similar to that of total algae. In August, both total algal and cyanobacterial densities were much higher than in other months.

Cell density $\left(x 10^{3}\right.$ cells $\left./ \mathrm{mL}\right)$
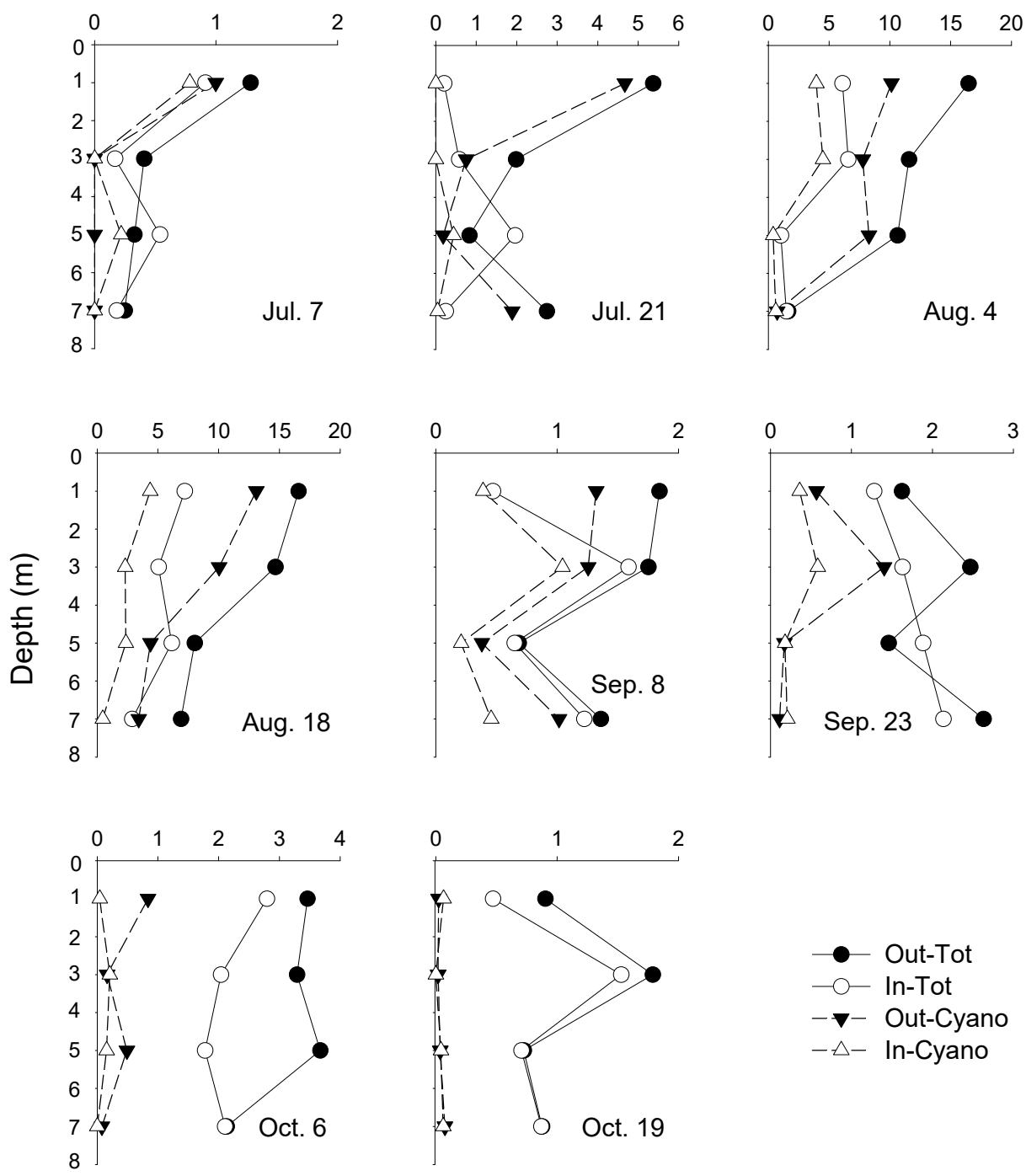

Figure 3. Vertical distributions of total algal and cyanobacterial densities on both the inside and the outside of the VWC during the study period. Out-Tot: total algae on the outside of the VWC; In-Tot: total algae on the inside of the VWC; Out-Cyano: cyanobacteria on the outside of the VWC; In-Cyano: cyanobacteria on the inside of the VWC. Note that the scales of the $x$-axes are different.

Outside of the VWC, total algal density ranged from 328 to 16,584 cells $/ \mathrm{mL}$, and cyanobacterial density varied from 0 to 13,104 cells $/ \mathrm{mL}$, accounting for $0-78 \%$ of total algae over all study depths. In contrast, total algal and cyanobacterial densities varied from 168 to 7208 and 0 to 4483 cells $/ \mathrm{mL}$, respectively, inside the VWC, with cyanobacteria accounting for $0-62 \%$ of total algae (Figure 3). 
In August, the cyanobacterial density was $4393-13,104$ cells / $\mathrm{mL}$ outside the VWC and significantly lower, at 394-4483 cells/mL, inside the VWC. Therefore, the VWC markedly reduced cyanobacteria by curtailing the high algal biomass inflow from the outside. In the middle of summer (August), during the cyanobacterial bloom, the VWC was particularly efficient at preventing the inflow of cyanobacteria into the water intake zone.

\subsection{Effects on Off-Flavors and Microcystins}

Off-flavor compounds (geosmin and 2-MIB) showed similar patterns, in terms of both ambient concentrations and reduction rates by the VWC, to those of cyanobacteria, indicating that cyanobacteria are mainly responsible for the occurrence of off-flavor materials in this study reservoir, which is consistent with prior studies $[16,17]$. Inside and outside the VWC, the concentrations of the off-flavor compound geosmin were 13-39 and 29-50 ng/L, respectively, while those of 2-MIB were 8-30 and $14-43 \mathrm{ng} / \mathrm{L}$, respectively (Figure 4).

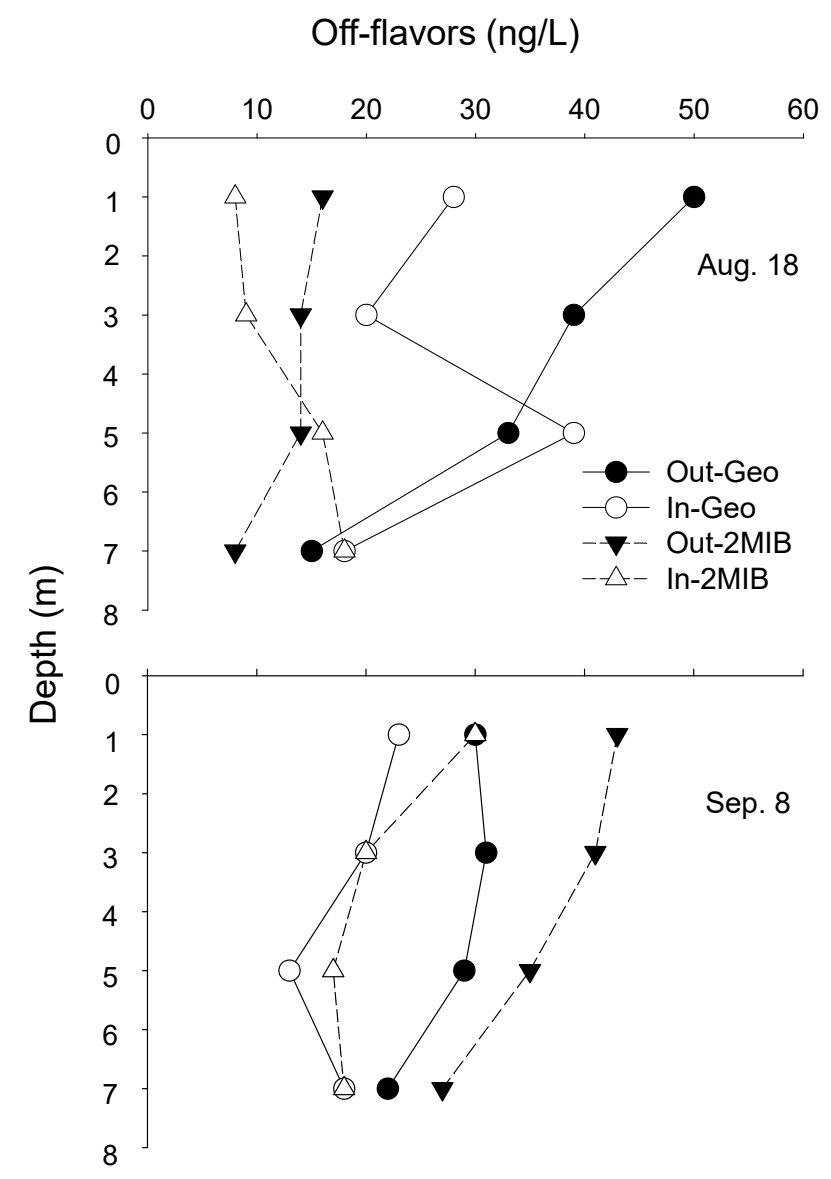

Figure 4. Vertical distributions of geosmin and 2-MIB concentrations on the inside and the outside of the VWC on 18 August and 8 September. Out-Geo: geosmin on the outside of the VWC; In-Geo: geosmin on the inside of the VWC; Out-2MIB: 2-MIB on the outside of the VWC; In-2MIB: 2-MIB on the inside of the VWC.

Concentrations of microcystins were higher on 18 August than on $7 \mathrm{July}$, in line with the increase in cyanobacterial density. Inside and outside the VWC, concentrations of microcystins were 0 and $0-0.079 \mu \mathrm{g} / \mathrm{L}$ for MC-LA, 0-0.129 and 0.040-1.222 $\mu \mathrm{g} / \mathrm{L}$ for MC-LR, 0.027-0.063 and 0.042-0.523 $\mu \mathrm{g} / \mathrm{L}$ for MC-RR, and 0-0.065 and 0-0.266 $\mu \mathrm{g} / \mathrm{L}$ for MC-YR, respectively (Figure 5). Among the microcystin derivatives observed in our study sites, MC-LR exhibited the highest concentration, followed by MC-RR, MC-YR, and MC-LA, particularly in the surface water $(1 \mathrm{~m})$. MC-LR concentrations higher 
than $1 \mu \mathrm{g} / \mathrm{L}$ were observed only when cyanobacteria (mainly Microcystis aeruginosa) accounted for $>50 \%$ of the total algae. On August 18 at a depth of $1 \mathrm{~m}$, where microcystins predominantly occur, the concentration of MC-LR reached a peak $(1.222 \mu \mathrm{g} / \mathrm{L})$ at a cyanobacterial density of $13,104 \mathrm{cells} / \mathrm{mL}$ outside the VWC. At the same time, MC-LR concentration was markedly lower $(0.129 \mu \mathrm{g} / \mathrm{L})$ at a cyanobacterial density of 4360 cells $/ \mathrm{mL}$ inside the VWC (Figures 3 and 5). Thus, the VWC markedly reduced cyanobacteria, off-flavors, and microcystins together.

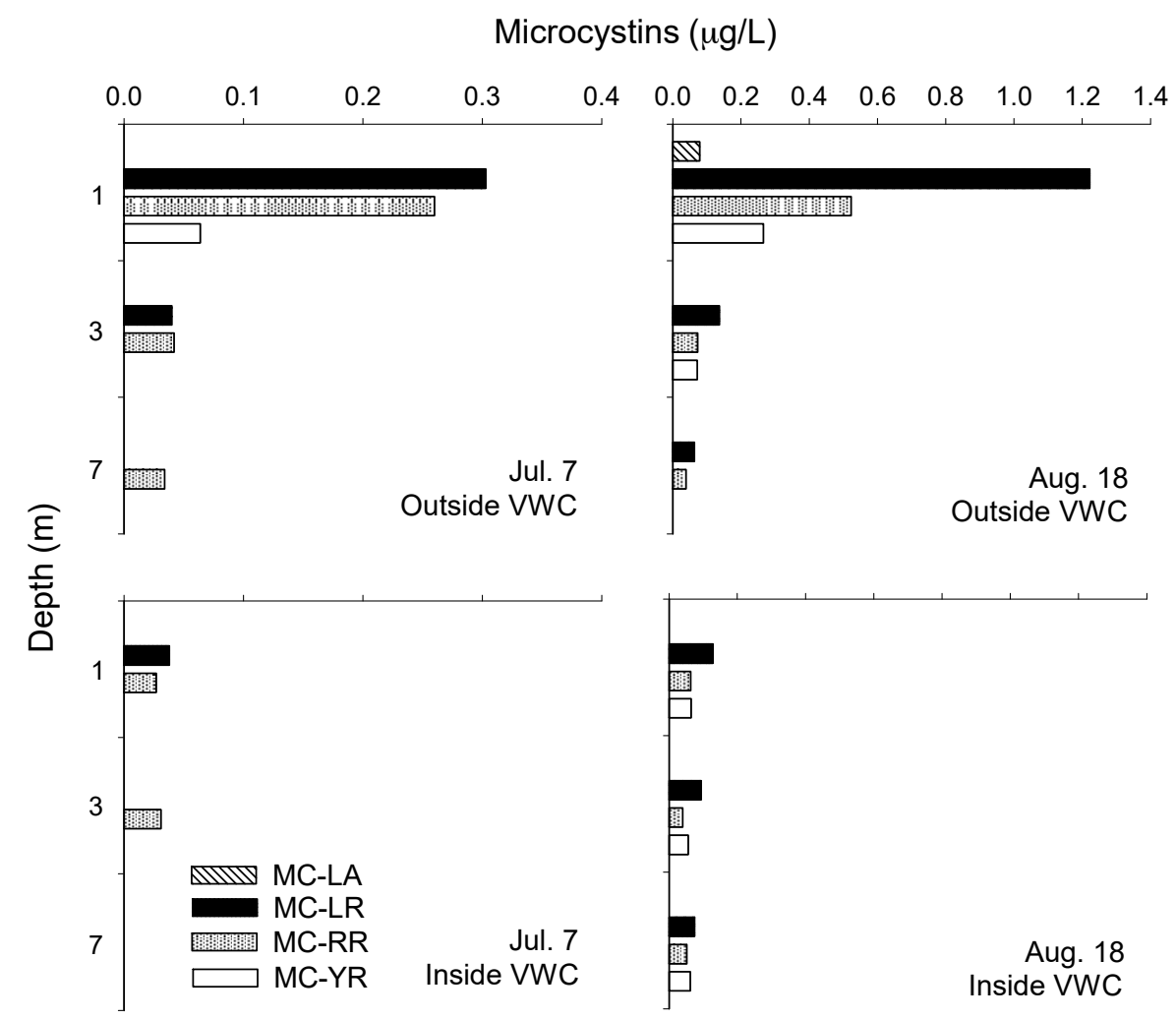

Figure 5. Vertical distributions of microcystin derivatives (MC-LA, MC-LR, MC-RR, and MC-YR) on the inside and the outside of the VWC on 7 July and 18 August. MC-LA: microcystin-LA; MC-LR: microcystin-LR; MC-RR: microcystin-RR; MC-YR: microcystin-YR.

\subsection{Reduction Efficiencies of Algae, Off-Flavors, and Microcystins}

Figure 6 shows the reduction rates (\%) for algae, off-flavor compounds, and microcystins by the VWC. All of these nuisance substances were markedly reduced on the inside of the VWC. Total algal and cyanobacterial densities for the collected samples were reduced by $40-59 \%$ and $60-75 \%$, respectively (Figure 6A). Geosmin and 2-MIB concentrations were reduced by $23-55 \%$ and $30-51 \%$, respectively (Figure 6B). The reduction of microcystins was most striking among the examined substances, particularly in the surface water: MC-LA, MC-LR, MC-RR, and MC-YR concentrations were reduced by $100 \%, 47-89 \%, 38-89 \%$, and $22-80 \%$, respectively (Figure $6 \mathrm{C}$ ).

Taking advantage of their easy construction and simple operation, physical algal-blocking measures such as algal fences and vertical curtains have often been used for water quality management. Some prior studies have reported the performances of such physical measures depending on algal compositions and cell densities in various water bodies, demonstrating reductions in Chl-a concentrations by $24-31 \%$ [9] and $11-56 \%$ [13] and reductions in algal cells by $40 \%$ [8,12]. The performance of the VWC in this study was potentially higher than these previously-reported values for cyanobacteria (Figure 6A). In addition, the VWC resulted in the effective reduction of nuisance metabolites of cyanobacterial origin, which was not looked for in prior studies. The relatively higher efficiency of the VWC in reducing microcystins than in reducing odorous compounds 
might be due to the fact that while odorous compounds are released even by actively-growing cyanobacterial cells, microcystins are contained within cells and are released only when cells are dead and decomposing $[27,28]$. We suspect that the blocking of cyanobacterial biomass by the VWC resulted in the reductions in odorous compounds and microcystins. We also speculate that the effective reductions in these substances can be attributed to the filtration resistance of the two combined curtains (waterproofing mat and particle blocking mat).
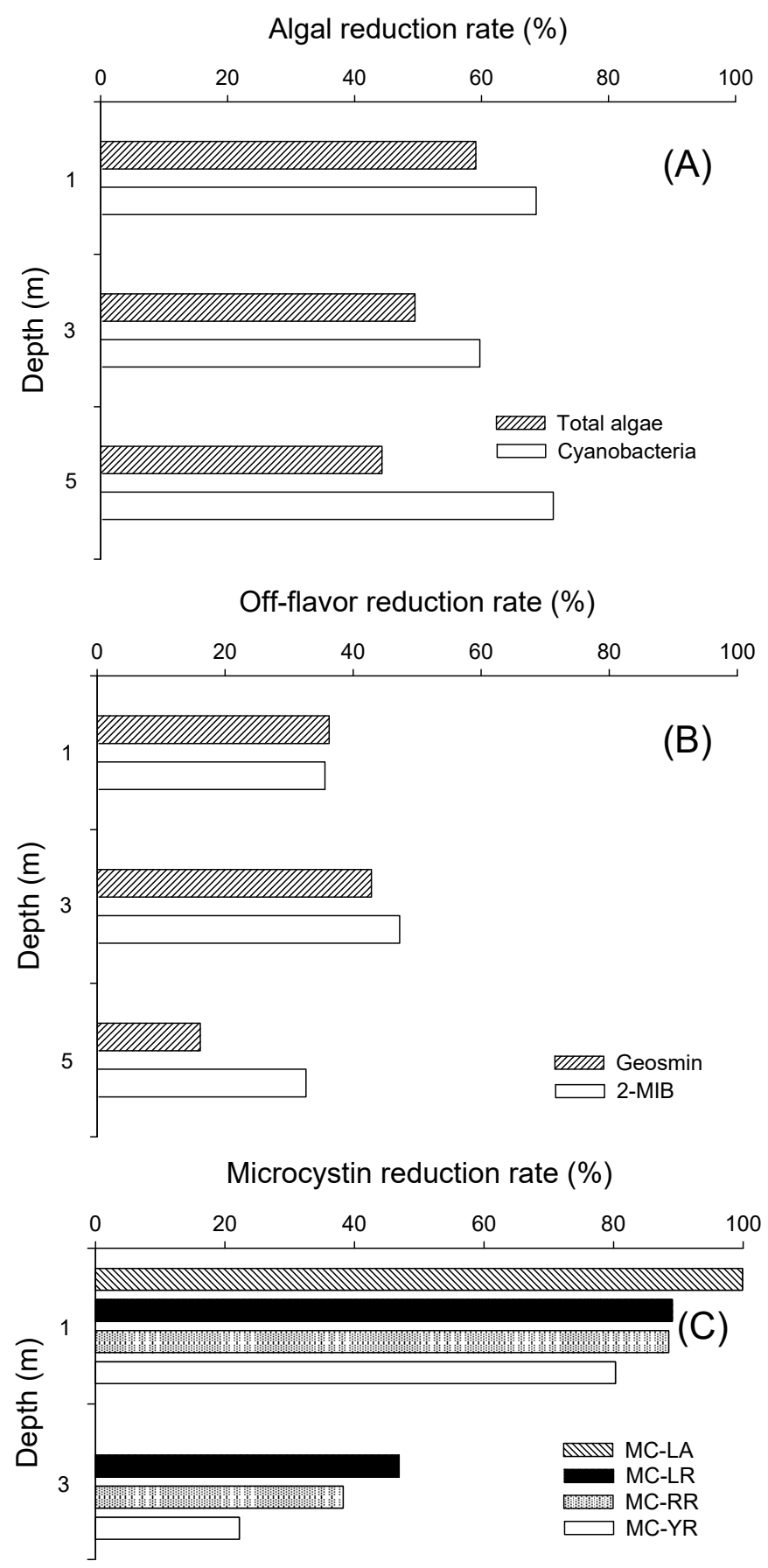

Figure 6. Mean reduction rates (\%) of algae, off-flavor compounds, and microcystin derivatives by the VWC at each sampling depth during the study period. (A) Total algae and cyanobacteria; (B) geosmin and 2-MIB; and (C) microcystin derivatives (MC-LA, MC-LR, MC-RR, and MC-YR). 
In this study, a VWC consisting of two combined mats was newly-designed as a pre-treatment method for mitigating levels of cyanobacteria and their metabolites. The removal of odor compounds is a difficult and costly task due to their extremely low threshold concentrations for human perception: $1.3 \mathrm{ng} / \mathrm{L}$ for geosmin and $6.3 \mathrm{ng} / \mathrm{L}$ for 2-MIB [11,29]. Thus, effective pre-treatment for these compounds in ambient water could increase the efficiency of the drinking water treatment process, thereby saving on operating costs. The VWC can also be applied potentially to cyanobacterial mitigation in other bodies of water, and it can be incorporated with other algal reduction measures for specific objectives.

\section{Conclusions}

The results of this study demonstrated the effectiveness and feasibility of the vertical weir curtain (VWC) as a physical pre-treatment method for mitigating cyanobacteria and some nuisance metabolites (odorants and cyanotoxins) in a drinking water intake zone during active algal growth and bloom periods. The main results and implications are as follows:

(1) The VWC could be a positive tool from the cyanobacterial mitigation perspective. Cyanobacteria were present at high levels during the summer in the drinking water reservoir, particularly in the surface water. The newly-designed VWC consisting of two mats (a waterproofing mat and particle blocking mat) limited the intrusion of cyanobacteria into the water intake zone in the collected samples.

(2) The VWC had an effective pre-treatment potential to reduce nuisance substances, such as cyanobacteria, geosmin, 2-MIB, and microcystins. Efficiency was particularly high when cyanobacteria were present at high densities.

(3) This method is simple, easy to construct, and effective compared to similar existing mitigation measures, such as algal fences. The VWC can be applied potentially in other water bodies including cyanobacterial hot spots, and it can be further incorporated with other methods as a systemic measure of algal reduction.

Acknowledgments: This work was supported by the Han River Watershed Management Commission in Korea (project name: Investigation of causes of off-flavor material production by harmful algae and management strategy) and the Small and Medium Business Administration (SMBA) in Korea (No. S2252412).

Author Contributions: All authors contributed the project. Chae-Hong Park wrote the manuscript with collaboration of Myung-Hwan Park. Keun-Hee Kim, Nan-Young Kim, and Young-Hyo Kim supported the sample collection and performed the algal and chemical analyses. Soon-Jin Hwang, Eun-Mi Gwon, Baik-Ho Kim, and Byung-Jin Lim conceived and designed the experiments, and co-authors participated in discussions and review of the manuscript.

Conflicts of Interest: The authors declare no conflict of interest.

\section{References}

1. Graham, J.L.; Loftin, K.A.; Meyer, M.T.; Ziegler, A.C. Cyanotoxin mixtures and taste- and-odor compounds in cyanobacterial blooms from the Midwestern United States. Environ. Sci. Technol. 2010, 44, 7361-7368. [CrossRef] [PubMed]

2. Korth, W.; Ellis, J.; Bowmer, K. The stability of geosmin and MIB and their deuterated analogues in surface waters and organic solvents. Water Sci. Technol. 1992, 25, 115-122.

3. Chorus, I.; Bartram, J. Toxic Cyanobacteria in Water: A Guide to Their Public Health Consequences, Monitoring and Management; E \& FN Spon: London, UK, 1999.

4. Glaze, W.H.; Schep, R.; Chauncey, W.; Ruth, E.C.; Zarnoch, J.J.; Aieta, E.M.; Tate, C.H.; McGuire, M.J. Evaluating oxidants for the removal of model taste and odor compounds from a municipal water supply. J. Am. Water Works Assoc. 1990, 82, 79-84.

5. Dabrowski, A.; Podkoscielny, P.; Hubicki, Z.; Barczak, M. Adsorption of phenolic compounds by activated carbon-A critical review. Chemosphere 2005, 58, 1049-1070. [CrossRef] [PubMed]

6. Newcombe, G.; Morrison, J.; Hepplewhite, C.; Knappe, D.R.U. Simultaneous adsorption of MIB and NOM onto activated carbon-II: Competitive effects. Carbon 2002, 40, 2147-2156. [CrossRef] 
7. Srinivasan, R.; Sorial, G.A. Treatment of taste and odor causing compounds 2-methylisoborneol and geosmin in drinking water: A critical review. J. Environ. Sci. 2011, 23, 1-13. [CrossRef]

8. Asaeda, T.; Priyantha, D.G.N.; Saitoh, S.; Gotoh, K. A new technique for controlling algal blooms in the withdrawal zone of reservoirs using vertical curtains. Ecol. Eng. 1996, 7, 95-104. [CrossRef]

9. Joo, G.J.; Jang, M.H.; Park, S.B.; Jung, J.M.; Roh, J.S.; Jeong, G.S. The application of an algal fence for the reduction of algal intake into the water intake facility. Korean J. Limnol. 2003, 36, 467-472.

10. Chen, X.C.; Kong, H.N.; He, S.B.; Wu, D.Y.; Li, C.J.; Huang, X.C. Reducing harmful algae in raw water by light-shading. Process Biochem. 2009, 44, 357-360. [CrossRef]

11. He, Q.; Zhong, L.; Wang, H.; Zou, Z.; Chen, D.; Yang, K. Odor removal by powdered activated carbon (PAC) in low turbidity drinking water. Water Sci. Technol. Water Supply 2016, 16, 1017-1023. [CrossRef]

12. Priyantha, D.G.N.; Asaeda, T.; Saitoh, S.; Gotoh, K. Modelling effects of curtain method on algal blooming in reservoirs. Ecol. Model. 1997, 98, 89-104. [CrossRef]

13. Lee, H.S.; Chung, S.W.; Choi, J.K.; Min, B.H. Feasibility of curtain weir installation for water quality management in Daecheong Reservoir. Desalin. Water Treat. 2010, 19, 164-172. [CrossRef]

14. Kim, J.K.; Lee, S.H.; Bang, H.H.; Hwang, S.O. Characteristics of algae occurrence in Lake Paldang. J. Korean Soc. Environ. Eng. 2009, 31, 325-331.

15. Park, M.H.; Lim, B.J.; Seo, W.B.; Park, C.H.; Kim, K.H.; Hwang, S.J. Akinete germination and algal growth potential test of cyanobacterium Anabaena circinalis on different waters in Lake Paldang. Korean J. Ecol. Environ. 2015, 48, 287-295. [CrossRef]

16. You, K.A.; Byeon, M.S.; Youn, S.J.; Hwang, S.J.; Rhew, D.H. Growth characteristics of blue-green algae (Anabaena spiroides) causing tastes and odors in the North-Han River, Korea. Korean J. Ecol. Environ. 2013, 46, 135-144. [CrossRef]

17. Byun, J.H.; Hwang, S.J.; Kim, B.H.; Park, J.R.; Lee, J.K.; Lim, B.J. Relationship between a dense population of cyanobacteria and odorous compounds in the North Han River system in 2014 and 2015. Korean J. Ecol. Environ. 2015, 48, 263-271. [CrossRef]

18. Park, H.G.; Jheong, W.H.; Kwon, O.S.; Ryu, J.K. Seasonal succession of toxic cyanobacteria and microcystins concentration in Paldang Reservoir. Algae 2000, 15, 29-35.

19. Standard Methods for the Examination of Water and Wastewater, 19th ed.; American Public Health Association/American Water Works Association/Water Environment Federation: Washington, DC, USA, 1995.

20. Akiyama, M.; Loiya, T.; Imahori, K.; Kasaki, H.; Kumano, S.; Kobayashi, H.; Takahashi, E.; Tsumura, K.; Hirano, M.; Hirose, H.; et al. Illustration of the Japanese Freshwater Algae; Uchidarockakuho Publishing Co., Ltd.: Tokyo, Japan, 1981.

21. Lloyd, S.W.; Lea, J.M.; Zimba, P.V.; Grimm, C.C. Rapid analysis of geosmin and 2-methylisoborneol in water using solid phase micro extraction procedures. Water Res. 1998, 32, 2140-2146. [CrossRef]

22. Watson, S.B.; Brownlee, B.; Satchwill, T.; Hargesheimer, E.E. Quantitative analysis of trace levels of geosmin and 2-MIB in source and drinking water using headspace SPME. Water Res. 2000, 34, 2818-2828. [CrossRef]

23. Kondo, F.; Ikai, Y.; Oka, H.; Ishikawa, N.; Watanabe, M.F.; Watanabe, M.; Harada, K.I.; Suzuki, M. Separation and identification of microcystins in cyanobacteria by frit-fast atom bombardment liquid chromatography/mass spectrometry. Toxicon 1992, 30, 227-237. [CrossRef]

24. Lawton, L.A.; Edwards, C.; Codd, G.A. Extraction and high-performance liquid chromatographic method for the determination of microcystins in raw and treated waters. Analyst 1994, 119, 1525-1530. [CrossRef] [PubMed]

25. Zhou, Q.; Chen, W.; Shan, K.; Zheng, L.; Song, L. Influence of sunlight on the proliferation of cyanobacterial blooms and its potential applications in Lake Taihu, China. J. Environ. Sci. 2014, 26, 626-635. [CrossRef]

26. Bowmer, K.H.; Padovan, A.; Oliver, R.L.; Korth, W.; Garf, G.G. Physiology of geosmin production by Anabaena circinalis isolated from the Murrumbidgee River, Australia. Water Sci. Technol. 1992, 25, $259-267$.

27. Harada, K.I.; Tsuji, K. Persistence and decomposition of hepatotoxic microcystins produced by cyanobacteria in natural environment. J. Toxicol.-Toxin Rev. 1998, 17, 385-403. [CrossRef] 
28. Zastepa, A.; Pick, F.R.; Blais, J.M. Fate and persistence of particulate and dissolved microcystin-LA from Microcystis blooms. Hum. Ecol. Risk Assess. 2014, 20, 1670-1686. [CrossRef]

29. Young, W.F.; Horth, H.; Crane, R.; Ogden, T.; Arnott, M. Taste and odour threshold concentrations of potential potable water contaminants. Water Res. 1996, 30, 331-340. [CrossRef] 